\title{
Philippine Sea Plate motion since the Eocene estimated from paleomagnetism of seafloor drill cores and gravity cores
}

\author{
Toshitsugu Yamazaki ${ }^{1}$, Masaki Takahashi ${ }^{1}$, Yasufumi Iryu ${ }^{2}$, Tokiyuki Sato $^{3}$, Motoyoshi Oda $^{4}$, Hideko Takayanagi $^{2}$, \\ Shun Chiyonobu ${ }^{4}$, Akira Nishimura ${ }^{1}$, Tsutomu Nakazawa ${ }^{1}$, and Takashi Ooka ${ }^{5}$ \\ ${ }^{1}$ Geological Survey of Japan, AIST, Tsukuba 306-8567, Japan \\ ${ }^{2}$ Graduate School of Environmental Studies, Nagoya University, Nagoya 464-8601, Japan \\ ${ }^{3}$ Institute of Applied Sciences, Mining College, Akita University, Akita 010-8502, Japan \\ ${ }^{4}$ Graduate School of Science, Tohoku University, Sendai 980-8578, Japan \\ 5 Japan Oil, Gas and Metals National Corporation, Kawasaki 212-8554, Japan
}

(Received April 28, 2009; Revised April 20, 2010; Accepted April 22, 2010; Online published August 6, 2010)

\begin{abstract}
Current models of Philippine Sea (PHS) Plate motion assume a general and large northward shift since the Eocene. In order to constrain better the age and amount of this northward shift, we have conducted a paleomagnetic study on drill and gravity cores, respectively, taken from the seafloor of the northern part of the PHS Plate. The core samples consist of sedimentary rocks or semi-consolidated sediments, and their ages, as estimated from microfossils and strontium isotope ratios, range from the Eocene to late Miocene. The results of stepwise alternating-field and thermal demagnetization experiments revealed that 19 sections at 17 sites out of 58 sections at the 29 sites examined yielded mean paleomagnetic directions with a 95\% confidence limit $\left(\alpha_{95}\right)$ of $<25^{\circ}$, and 14 sections at 13 sites have $\alpha_{95}<15^{\circ}$. An estimation of the amount of the northward shift at each site was obtained from the difference between the paleolatitude and the present latitude. This estimation revealed that the northern part of the PHS Plate was located near the equator at $50 \mathrm{Ma}$ and that the majority of the northward shift took place between about 50 and $25 \mathrm{Ma}$. Very little northward movement occurred after $15 \mathrm{Ma}$. Based on our data, together with the available paleomagnetic information suggesting clockwise rotation of about $90^{\circ}$ since the Eocene and the requirements from geometry with the surrounding plates, we present a model in which the PHS Plate rotated $90^{\circ}$ clockwise between 50 and $15 \mathrm{Ma}$ on the Euler pole near $23^{\circ} \mathrm{N}, 162^{\circ} \mathrm{E}$, although it is impossible to specifically determine the Euler pole position.
\end{abstract}

Key words: Eocene, Euler pole position, Miocene, plate motion, paleolatitude, paleomagnetic directions, Philippine Sea Plate.

\section{Introduction}

The Philippine Sea (PHS) Plate in the western Pacific (Fig. 1) was formed through intermittent backarc spreading. The spreading of the West Philippine Basin, which occupies the western part of the PHS Plate, is considered to have occurred from about 54 to $30 \mathrm{Ma}$ at the Central Basin Fault (Hilde and Lee, 1984; Deschamps and Lallemand, 2002), although its opening process is not yet well understood. The formation of the Shikoku and Parece Vela Basins occurred from about 27 to $15 \mathrm{Ma}$ (Okino et al., 1994, 1999), and it split the proto-Izu-Ogasawara (Bonin)-Mariana (IBM) Arc into the Kyushu-Palau Ridge and the present IBM Arc. The Mariana Trough started opening at about $6 \mathrm{Ma}$ (Yamazaki and Stern, 1997; Iwamoto et al., 2002). The Daito Ridge, Oki-Daito Ridge, and Amami Plateau, all of which are probably arc fragments of Cretaceous age (Hickey-Vargas, 2005), reside in the northern part of the PHS Plate west of the Kyushu-Palau Ridge.

The history of PHS Plate motion is not yet well under-

Copyright (c) The Society of Geomagnetism and Earth, Planetary and Space Sciences (SGEPSS); The Seismological Society of Japan; The Volcanological Society of Japan; The Geodetic Society of Japan; The Japanese Society for Planetary Sciences; TERRAPUB.

doi:10.5047/eps.2010.04.001 stood. At the present time, the PHS Plate is a small plate, and there is no hotspot track that documents plate motion. Furthermore, most of the plate is submerged, rendering it difficult to construct a virtual geomagnetic pole (VGP) path using fully oriented paleomagnetic samples. Paleomagnetic data are available for islands along the eastern margin of the plate, such as the Ogasawara (Bonin) islands, Guam, Saipan, and Palau (Kodama et al., 1983; Haston et al., 1988; Haston and Fuller, 1991), for eastern Indonesia, which occupies the southernmost part of the PHS Plate (Hall et al., 1995a, b), and for drill cores of the Ocean Drilling Program (ODP) Leg 126 from the northern part of the IBM Arc (Koyama et al., 1992). However, a VGP path could not be constructed because of the possibility for local movement in the tectonically active regions and limited age distribution. Therefore, with the exception of the eastern and southern margins, paleomagnetic data on the PHS Plate are limited to data obtained from the cores of the Deep-Sea Drilling Project (DSDP) in the 1970s taken from the West Philippine Basin, Shikoku and Parece Vela Basins, and Daito Ridge (Louden, 1977; Kinoshita, 1980). However, the quality of these data may not be high enough by modern standards because (1) these cores were drilled by a rotary core barrel and, as such, they may have been physically disturbed and 


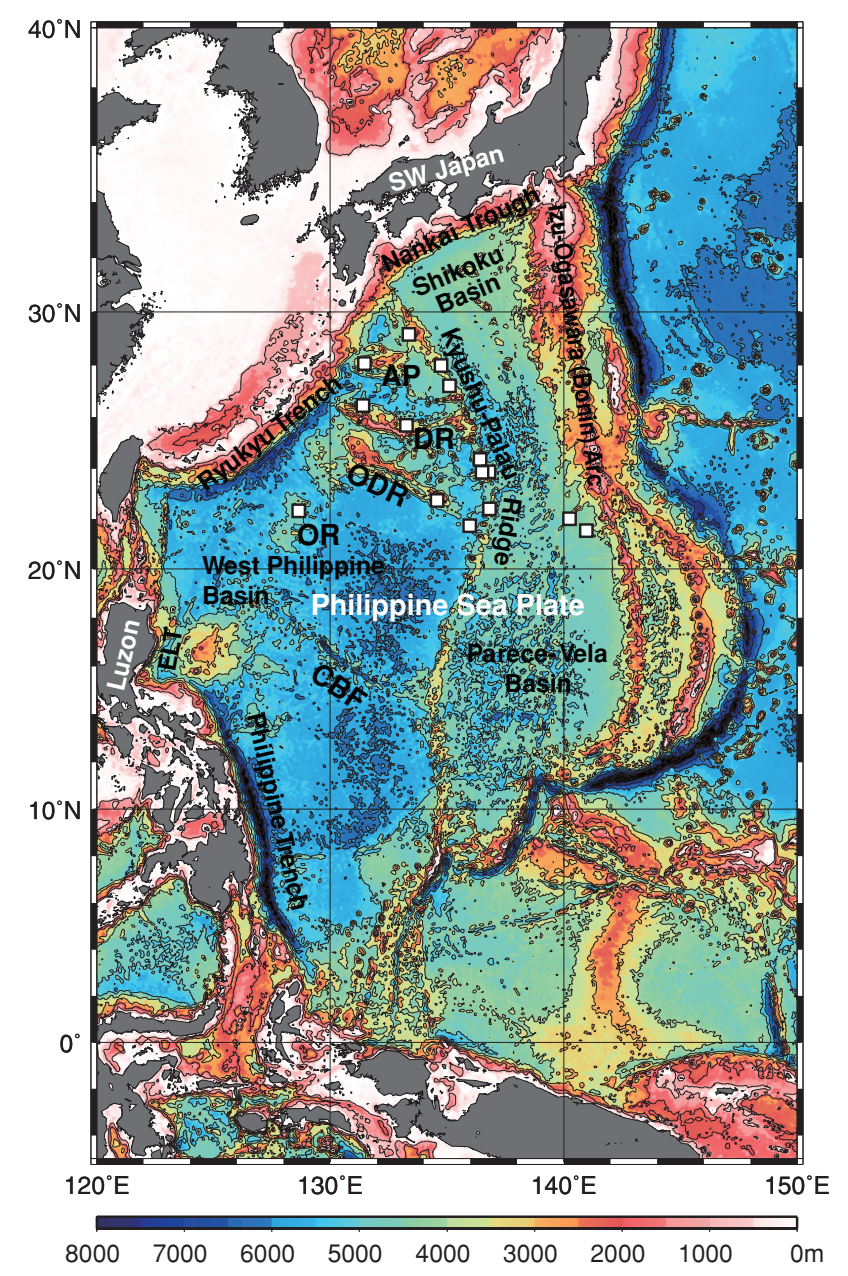

Fig. 1. Bathymetry of the Philippine Sea (PHS) Plate and its surroundings. Open squares are the drilling or coring sites from which paleolatitudes were obtained. AP: Amami Plateau, DR: Daito Ridge, ODR: Oki-Daito Ridge, OR: Okinawa Rise (Urdaneta Plateau), CBF: Central Basin Fault, ELT: East Luzon Trough.

(2) complete demagnetization experiments were not conducted. Nevertheless, the paleomagnetic data on the PHS Plate that are available show a general and large northward shift of the plate since the Eocene. These data have been incorporated into models of PHS Plate motion which also generally assume a large northward movement since the Eocene (e.g., Seno and Maruyama, 1984; Hall et al., 1995a, b, c; Hall, 2002), but the distance of the movement and variation in speed over time have not yet been well documented. ODP recently occupied again the West Philippine Basin at a single site (Site 1201), but the paleomagnetic data failed to continuously track PHS Plate motion because of the occurrence of large hiatuses (Shipboard Scientific Party, 2002).

We have conducted a paleomagnetic study of drill cores and gravity cores newly taken from the northern part of the PHS Plate in order to better constrain the age and amount of the northward shift. We present a model of PHS Plate motion using these newly acquired data.

\section{Samples and Measurements}

Drill cores of consolidated sediment taken with a deepsea Boring Machine System (BMS) (Matsumoto and Sarata, 1996; Matsuda et al., 2004) of R/V Hakurei-maru
No. 2 were used in this study. The BMS can drill through rocks down to a maximum depth of $20 \mathrm{~m}$ below the seafloor by remote operation from the vessel through an armored cable and take cores $47 \mathrm{~mm}$ in diameter. Drilling was conducted at topographic highs with no or little unconsolidated sediment cover. The drilling sites were chosen based on the strength of acoustic reflection from the seafloor and were distributed on the Kyushu-Palau Ridge, Amami Plateau, Daito Ridge, Oki-Daito Ridge, Okinawa Rise (Urdaneta Plateau), and the northeasternmost part of the Parece Vela Basin (Fig. 1). Short semi-consolidated sediment cores taken with a gravity corer were also included in this study.

From drill cores of the BMS, we selected a core piece longer than $\sim 10 \mathrm{~cm}$ (called a 'section' in this paper) for the paleomagnetic measurements. Each section was not oriented azimuthally, but the relative declination within it can be discussed. Two cubic specimens of about $2 \mathrm{~cm}$ each side were cut from each horizon with a diamond saw, and a total of eight or more specimens were obtained from each section. Samples from the gravity cores were in the form of cubes, about $7 \mathrm{~cm}^{3}$ each, and were taken by inserting plastic cubes into half-split core surfaces or by gouging with a special apparatus made of stainless steal. Paleomagnetic measurements were carried out for 55 sections at 26 sites of BMS cores and three sites of 1- to 2-m-long gravity cores.

A cryogenic magnetometer system with an in-line alternating-field (AF) demagnetizer (2G Enterprises model 760) and a thermal demagnetizer (Magnetic Measurement MMTD-18), both of which are located in a magnetically shielded room of the Geological Survey of Japan, AIST, were used for the paleomagnetic measurements. Stepwise $\mathrm{AF}$ and thermal demagnetization experiments were performed on pilot specimens with the aim of examining the stability of the remanent magnetization. If the results of the $\mathrm{AF}$ and thermal demagnetizations were in agreement, the rest of the specimens were AF demagnetized progressively. Otherwise, stepwise thermal demagnetization was applied to the remaining specimens. The direction of the remanent magnetization was determined by applying principal component analysis (Kirschvink, 1980) to the demagnetization data. Specimens with the maximum angular deviation (MAD) $>20^{\circ}$ were rejected as unreliable. Typical examples of the stepwise demagnetization results are given in Fig. 2 for accepted specimens. When four or more horizons yielded acceptable paleomagnetic directions, the mean direction and $95 \%$ confidence limit $\left(\alpha_{95}\right)$ were calculated using the Fisher statistics. The mean direction of the two specimens from the same horizon was used for the calculation if both survived. The depth intervals of two core sections from a single site were regarded as a single section when they were in close $(8.75-8.90 \mathrm{~m}$ below the seafloor (mbsf) of the KP357 Seamount, 5.25-5.50 mbsf of the Hazuki Seamount, 2.43-2.58 mbsf of the Shinsei Seamount, and 6.48-6.71 mbsf of the Iwoto Trough SE; Table 1), and the mean inclination was calculated using the inclination only statistics of Arason and Levi (2006). This also applies to the gravity cores at the Meisei and Hokuto Seamounts; the declination data could not be used because they were possibly influenced by core twisting. Sections with a $95 \%$ confidence limit $>25^{\circ}$ were rejected. We attempted to orient the 
(a) Osumi Seamount (0.50-0.60 mbsf)
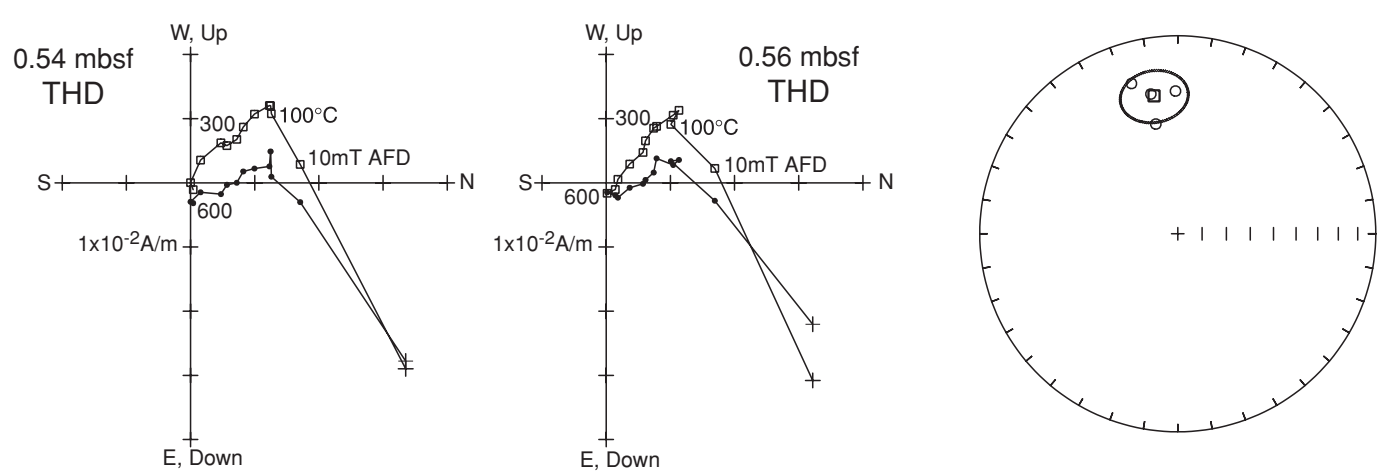

(b) Hyuga Seamount (11.87-12.00 mbsf)
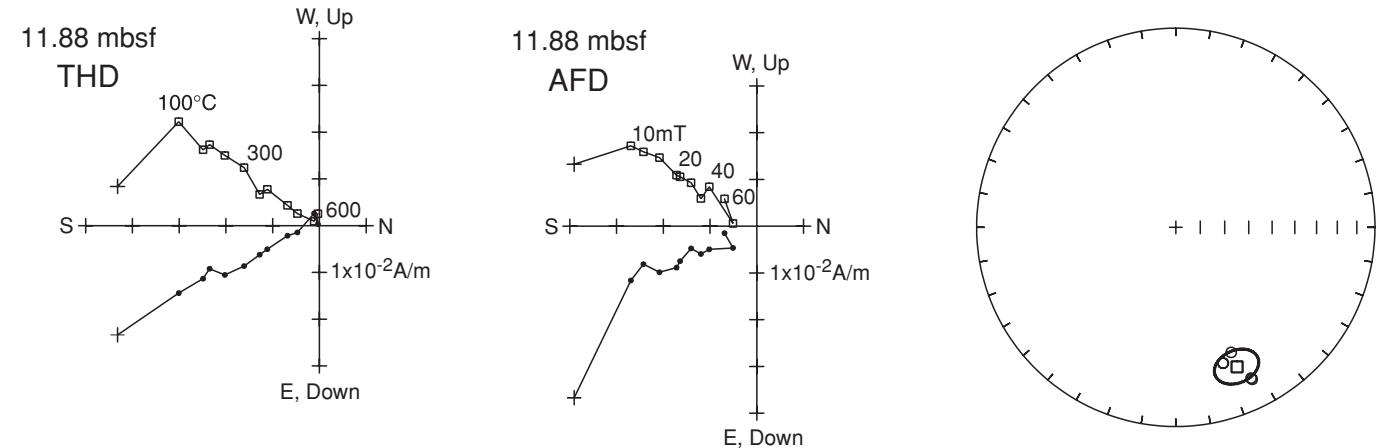

(c) Naze Seamount $(0.58-0.70 \mathrm{mbsf})$
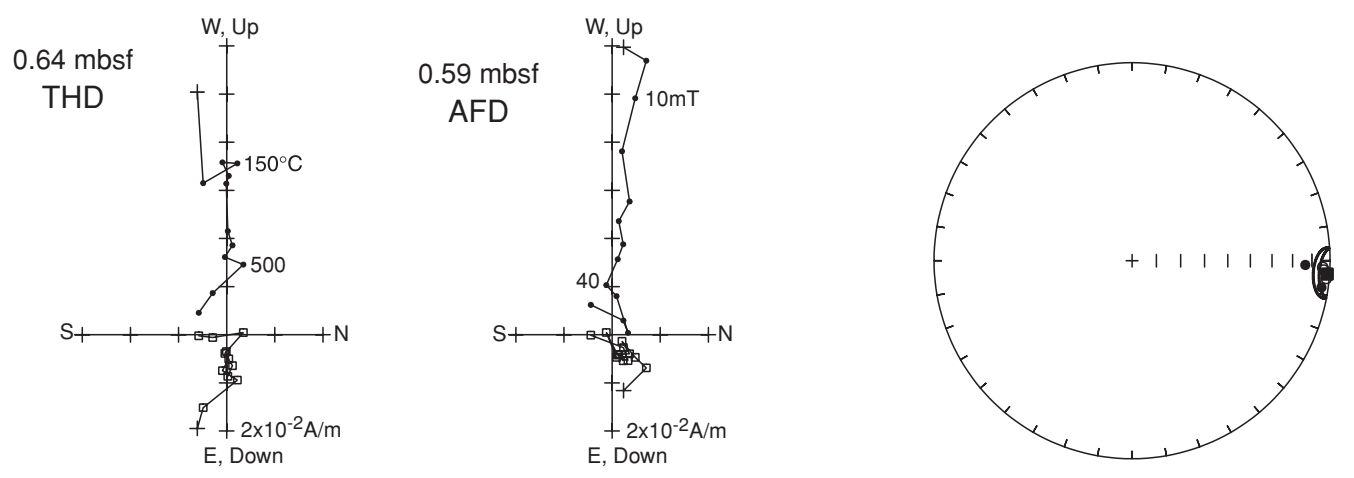

(d) Shichigosan Knoll (2.46-2.64 mbsf)
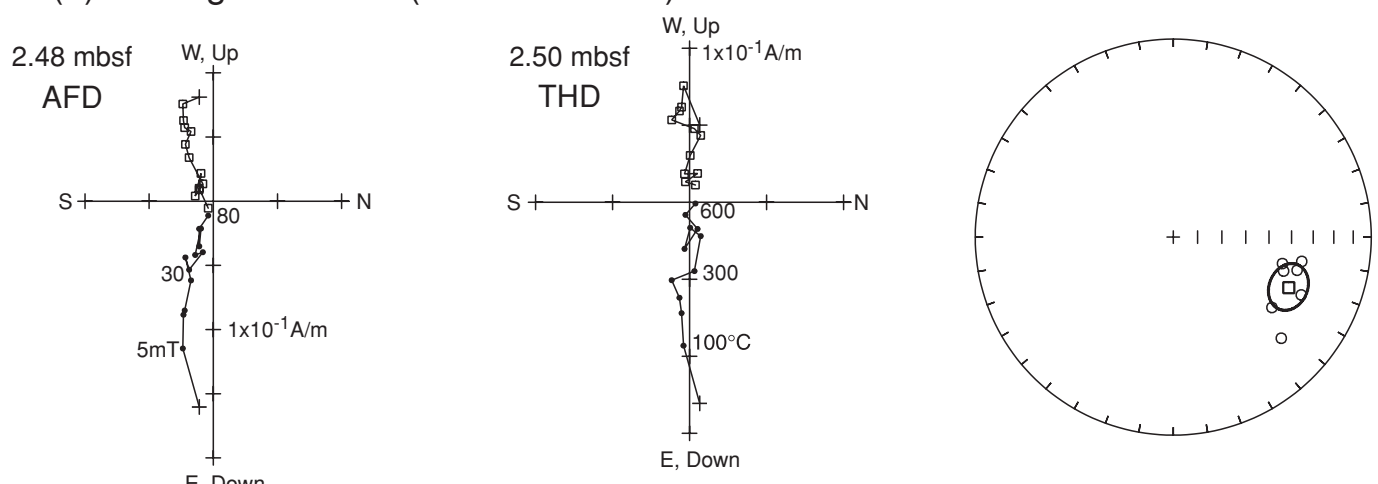

Fig. 2. Examples of stepwise alternating-field (AF) and thermal (TH) demagnetization data, which were selected from the sections accepted as reliable. Open (solid) circles are projection of vector end-points on the vertical (horizontal) plane. Declination is relative because cores are not oriented azimuthally. Right column is equal-area projection of paleomagnetic direction of each horizon (circle), and the site mean direction (square) and 95\% confidence limit. 


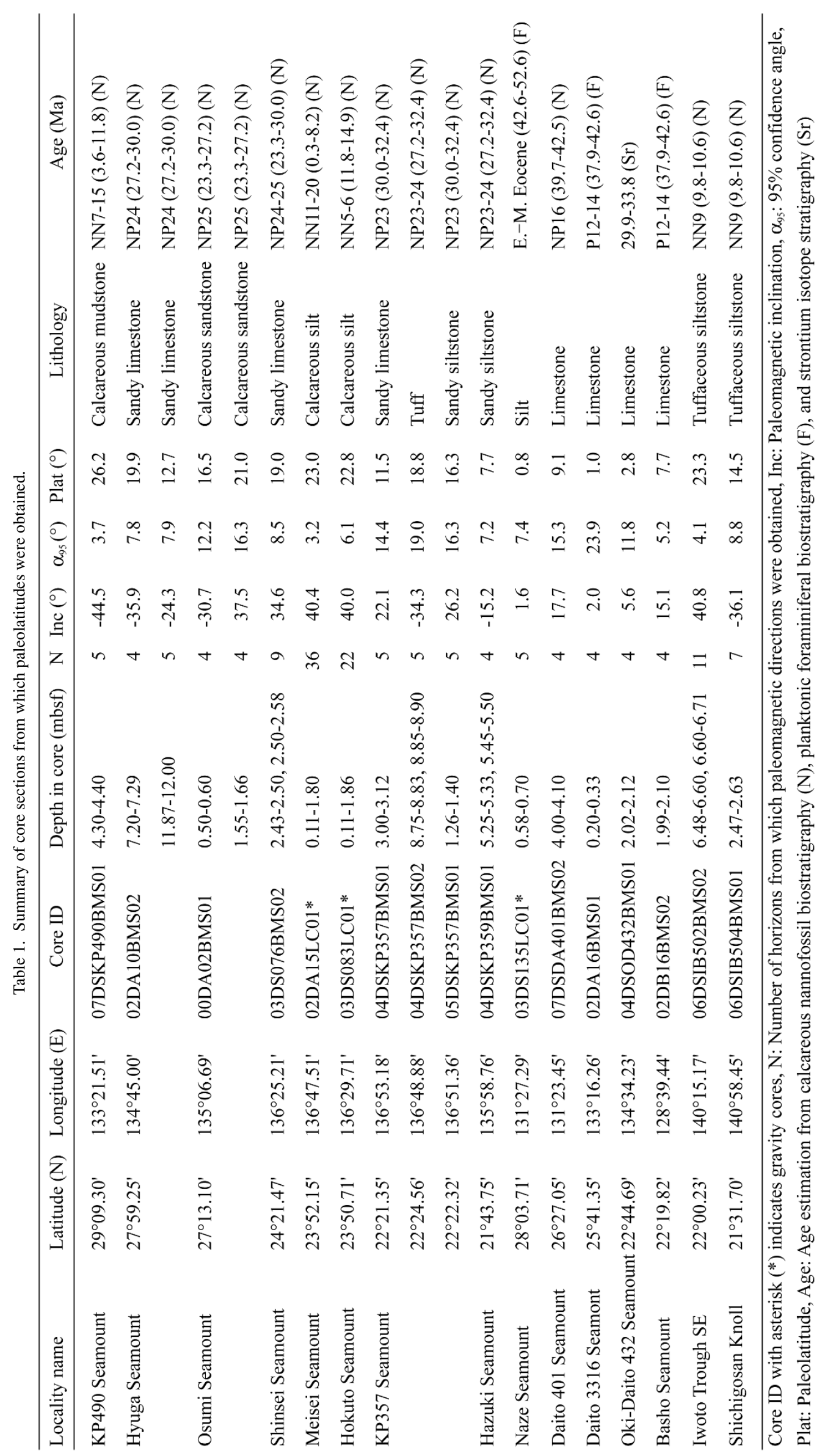


cores azimuthally using viscous remanent magnetization of the present-day field direction, but were relatively unsuccessful partly because of secondary magnetization that was probably acquired at or after drilling.

Age control of the core sections is based on calcareous nannofossil biostratigraphy, planktonic foraminiferal biostratigraphy, or strontium isotope $\left({ }^{87} \mathrm{Sr} /{ }^{86} \mathrm{Sr}\right)$ stratigraphy (Table 1). The sections of the paleomagnetic measurements are at the same depths as, or nearby to the horizons of microfossil analyses or isotope measurements, or they are between two horizons of age determination. The ages of the studied samples range from the Eocene to late Miocene. The timescale of Gladstein et al. (2004) was used in this study. It is difficult to determine sedimentation rates, and thus it was not possible to judge that secular variations in the geomagnetic field could be averaged out for the depth intervals of $10-20 \mathrm{~cm}$ of each section. However, sedimentation slow enough for averaging out secular variations is expected in general from the pelagic environment of the study area and the distribution of the drilling sites on topographic highs.

\section{Results}

The mean paleomagnetic inclinations were obtained from 19 sections at 17 sites (Fig. 1, Table 1). The successful sites include three gravity cores. A polarity reversal was found in two core sections, namely, at 1.55-1.66 mbsf at the Osumi Seamount and 0.20-0.33 mbsf at the Daito 3316 Seamount, and three reversals occur in the gravity cores from the Meisei and Hokuto Seamounts. These results support the inference that sedimentation rates would be low in general. The direction of the reversed polarity was converted to the antipodal direction for calculating the mean direction. The paleolatitude of each site was calculated from the mean inclination. The magnitude of northward motion was determined from the difference between the present latitude and the paleolatitude of each site (Table 1, Fig. 3). When calculating paleolatitudes, negative mean in-

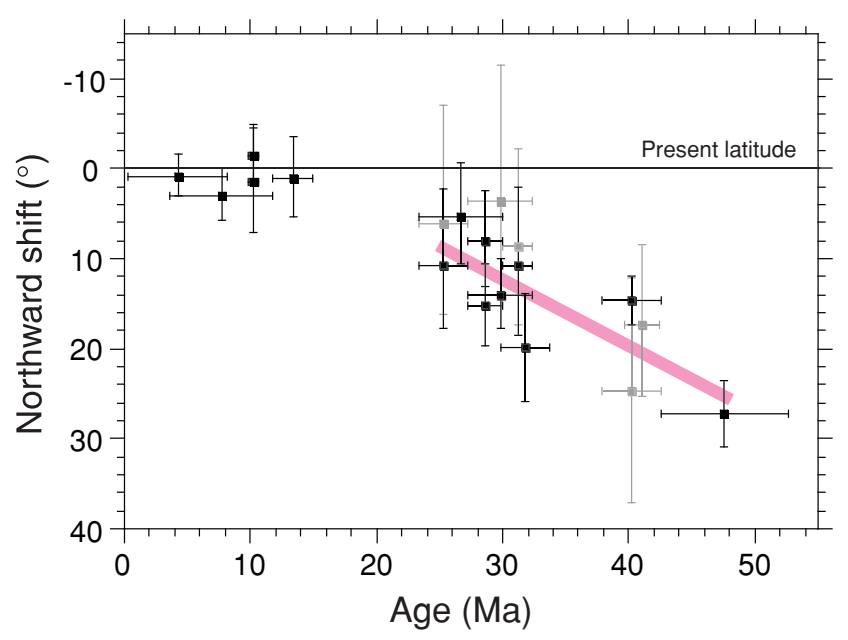

Fig. 3. Amount of northward shift in latitude for each site. Solid squares are the sites having paleomagnetic directions with $95 \%$ confidence limit $\left(\alpha_{95}\right)$ that are $<15^{\circ}$, gray squares are the sites with $15^{\circ}<\alpha_{95}<25^{\circ}$ Red line shows the linear least square fitting to the sites with $\alpha_{95}<15^{\circ}$ and older than $20 \mathrm{Ma}$. clinations were treated as the reversed polarity, assuming that no site crossed the equator.

The analyses revealed that since the Eocene, the studied area has moved in a northward direction by as much as $\sim 25^{\circ}$ in latitude. The present northern part of the PHS Plate was located near the equator at $\sim 50 \mathrm{Ma}$. The majority of the movement took place between the Eocene and Oligocene (at approx. 50-25 Ma), and the movement since the middle Miocene, $\sim 15 \mathrm{Ma}$, is small. The average northward velocity component obtained from the linear least square fitting to the data before $\sim 20 \mathrm{Ma}$ is approximately $8.0 \mathrm{~cm} /$ year, when only the sites of higher reliability with $\alpha_{95}<15^{\circ}$ are included in the calculation. The section 8.75-8.90 mbsf at the KP357 Seamount was excluded for the reason that secular variation could not be averaged based on its lithology, namely, tuff.

\section{Discussion}

Our observation that the majority of the northward movement of the PHS Plate occurred before $\sim 25 \mathrm{Ma}$ is consistent with the geology of the Japanese Islands. The collision of the IBM Arc against the Southwest Japan Arc is considered to have started at about $15 \mathrm{Ma}$, and the location of the collision has not moved significantly since then (e.g., Amano, 1991; Takahashi and Saito, 1999). This result indicates that the direction of the PHS Plate motion since 15 Ma should be almost northward, perpendicular to the strike of the Nankai Trough in the collision zone. Because the formation of the volcanic front of the Southwest Japan Arc in the Quaternary indicates the arrival of the edge of the PHS Plate slab under the front at the depth of about $110 \mathrm{~km}$ (Kimura et al., 2005), the length of the subducted slab is estimated to be about $380 \mathrm{~km}$, which amounts to a movement of $\sim 3.5^{\circ}$ in terms of latitude. Such a small amount is close to the uncertainty of paleomagnetism and consistent with the result showing little northward shift since $\sim 15 \mathrm{Ma}$. At the present time, the PHS Plate motion relative to Eurasia is northwestward, with a velocity of approximately $3 \mathrm{~cm} /$ year at the easternmost part of the Nankai Trough (Seno et al., 1993; Kato et al., 1998), but the direction changed to the current direction at about $3 \mathrm{Ma}$ or later (Nakamura et al., 1984; Jolivet et al., 1989; Yamazaki and Okamura, 1989). Thus, the direction for the last $15 \mathrm{Ma}$ can be regarded as north on average. It is assumed that the PHS Plate did not show any large northward movement during the spreading of the Shikoku Basin, which occurred from $\sim 27$ to $15 \mathrm{Ma}$ (Okino et al., 1994). This assumption is based on the lack of geological evidence for a collision of the IBM Arc at any place along the Nankai Trough when the IBM Arc migrated from the location of the Kyushu-Palau Ridge to its present position associated with the opening of the Shikoku Basin.

Easterly deflected paleomagnetic directions of up to $\sim 90^{\circ}$ in the Eocene have been reported from the eastern and southern margin of the PHS Plate (Kodama et al., 1983; Haston et al., 1988; Haston and Fuller, 1991; Koyama et al., 1992; Hall et al., 1995a, b). According to the compilation by Haston and Fuller (1991), the paleomagnetic declinations obtained from the eastern margin of the PHS Plate can be summarized as $D=105.3^{\circ} \pm 12.6^{\circ}$ and $91.7^{\circ} \pm 16.9^{\circ}$ in the Eocene from the Bonin Islands of Chichijima and 


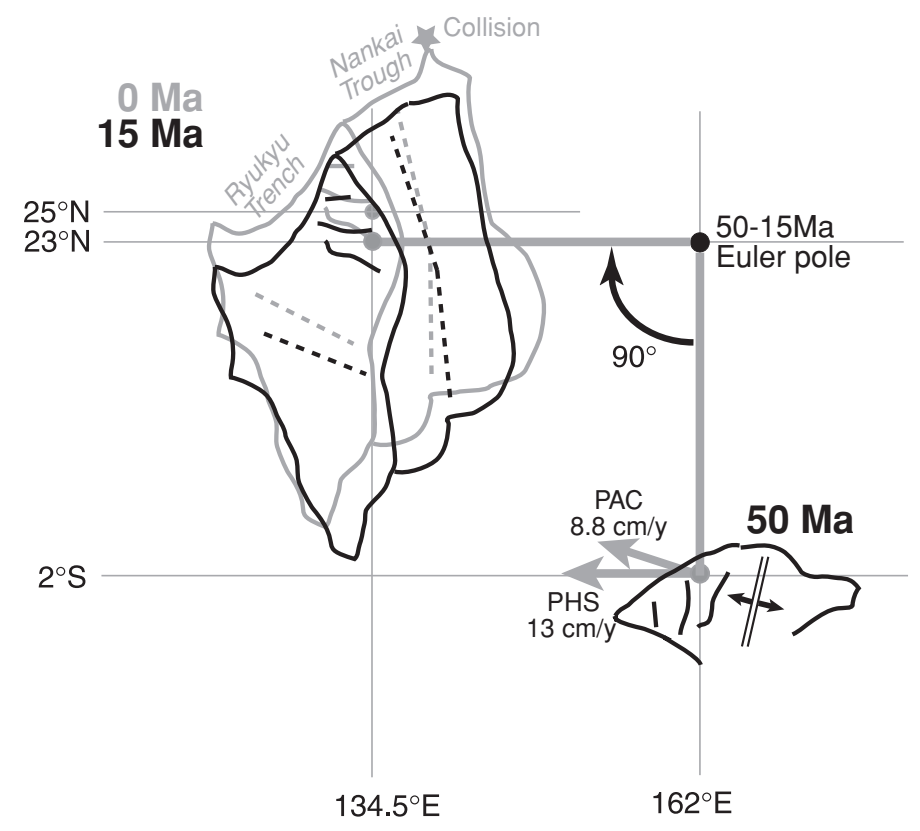

Fig. 4. A model of the Philippine Sea Plate motion. The PHS Plate rotated clockwise by $90^{\circ}$ around the Euler pole at $23^{\circ} \mathrm{N}, 162^{\circ} \mathrm{E}$ between 50 and $15 \mathrm{Ma}$, and then the pole position changed to the east of the collision zone between IBM and SW Japan Arcs (see text).

Anijima, respectively; $D=43.0^{\circ} \pm 12.5^{\circ}$ in the lower Eocene from Saipan; $D=68.4^{\circ} \pm 12.8^{\circ}$ in the middle Oligocene from Palau; $D=66.1^{\circ} \pm 11.1^{\circ}$ in the middle Oligocene from Guam; $D=54.5^{\circ} \pm 17.4^{\circ}$ in the lower Miocene from Palau; $D=30.7^{\circ} \pm 8.4^{\circ}$ in the middle Miocene from Saipan. Declinations of $85.7^{\circ} \pm 15.9^{\circ}$ at $47 \pm 3 \mathrm{Ma}, 39.1^{\circ} \pm 19.5^{\circ}$ at $40 \pm 2 \mathrm{Ma}$, and $\sim 40^{\circ}$ from 27 to $33 \mathrm{Ma}$ have been reported in eastern Indonesia (Hall et al., 1995a). Kodama et al. (1983) suggested that the easterly deflected declinations from the Bonin Islands are due to local tectonic rotations associated with left-lateral strikeslip faults. However, it would be better to consider that the entire PHS Plate rotated clockwise because all islands show concordant rotations (Haston and Fuller, 1991). In addition, the skewness of magnetic anomalies in the West Philippine Basin also suggests a similar clockwise rotation (Louden, 1977; Shih, 1980). The compilation of the then available paleolatitude data from the PHS Plate by Koyama et al. (1992, figure 11) revealed a tendency for the range of paleolatitude distribution to decrease with increasing age and a decrease in the mean paleolatitude, suggesting that the site distribution was originally close to E-W in low latitudes and then changed to N-S. This scenario is consistent with the clockwise rotation of about $90^{\circ}$.

We present a possible model for the motion of the PHS Plate between 50 and $15 \mathrm{Ma}$ based on the paleomagnetic constraints: clockwise rotation by $90^{\circ}$ around the Euler pole at $23^{\circ} \mathrm{N}, 162^{\circ} \mathrm{E}$ with the mean angular velocity of $2.57^{\circ} / \mathrm{m}$.y. (Fig. 4). The sampling sites are represented by the approximate center of the site distribution at $25^{\circ} \mathrm{N}, 134.5^{\circ} \mathrm{E}$. From Fig. 3, the latitudes at 50 and $15 \mathrm{Ma}$ can be estimated to be $2^{\circ} \mathrm{S}$ and $23^{\circ} \mathrm{N}$, respectively. We assume that the northward shift was caused only by the $\sim 90^{\circ}$ clockwise rotation of the PHS Plate and ignore the contribution of the opening of the West Philippine Basin. The size of the plate actually increased in association with the opening; as such, it could have contributed partly to the northward shift of the northern part of the PHS Plate if it opened northward in the present geometry (westward in the geometry at $50 \mathrm{Ma}$ ). It is impossible to determine the position of the Euler pole of the PHS Plate rotation specifically from only the conditions mentioned above. However, this model can satisfy both the paleomagnetic constraints and the geometry with the surrounding plates that requires subduction of the Pacific Plate along the IBM Trench and subduction of the PHS Plate along the Ryukyu Trench. In this model, the speed of the PHS Plate motion between 50 and $15 \mathrm{Ma}$ is calculated to be as fast as approximately $13 \mathrm{~cm} /$ year from the mean angular velocity. It is faster than the Pacific Plate motion at $2^{\circ} \mathrm{S}$, $162^{\circ} \mathrm{E}$, which is $8.8 \mathrm{~cm} /$ year toward $289^{\circ}$ as calculated from the Euler pole and rotation angle over a hotspot reference frame after the Hawaii-Emperor bend (Duncan and Clague, 1985). Consequently, it is possible to form a convergent margin along the northern part of the Kyushu-Palau Ridge at or a little later than the $50 \mathrm{Ma}$ required from the initiation of arc volcanism at that time (Ishizuka et al., 2006), which is probably associated with the Pacific Plate motion change at $\sim 50 \mathrm{Ma}$ (Sharp and Clague, 2006). If the Euler pole is much closer to the PHS Plate than our model-for example, near the southern end of the PHS Plate-the northwestward velocity component produced at the Ryukyu Trench is very minor, and hence it would be difficult to constitute convergence there. The PHS Plate slab subducted from the Ryukyu Trench is visible as a high $P$-wave velocity zone down to at least $300 \mathrm{~km}$ in the mantle tomography images of Huang and Zhao (2006), which could be traced further down to $600 \mathrm{~km}$ in their figures $8(\mathrm{~d})$ and $10(\mathrm{~h})$. The existence of a long slab indicates long continued subduction. If, on the other hand, the Euler pole is much farther, the studied sites should initially have moved southward and then changed to a northward motion, which is not supported by the paleomagnetic observation. Furthermore, the speed of 
the motion becomes unrealistically fast.

Hall et al. (1995a, b, c) proposed a model in which the PHS Plate rotated clockwise by $34^{\circ}$ between 25 and $5 \mathrm{Ma}$ around the Euler pole at $15^{\circ} \mathrm{N}, 160^{\circ} \mathrm{E}$, by $50^{\circ}$ between 50 and $40 \mathrm{Ma}$ around the pole at $10^{\circ} \mathrm{N}, 150^{\circ} \mathrm{E}$, and no rotation between 40 and $25 \mathrm{Ma}$. Sdrolias et al. (2004) further limited the period of the younger rotation to be between 15 and $5 \mathrm{Ma}$. However, these models are inconsistent with the PHS Plate motion towards north along the Nankai Trough since 15 Ma deduced from the collision of the IBM Arc against the Southwest Japan Arc mentioned above. Furthermore, based on the volcanic activity in southwestern Japan, the subduction of the hot Shikoku Basin lithosphere beneath the Southwest Japan is considered to have occurred between 17 and 12 Ma concurrently from Kyushu to central Japan just west of the IBM Arc collision zone (Kimura et al., 2005). There is no evidence that the area subducted by the hot Shikoku Basin gradually extended eastward with time, which is predicted from the model proposed by Hall and others. In addition, magnetic anomaly skewness of the Shikoku Basin supports no significant rotation since $\sim 20 \mathrm{Ma}$ (Chamot-Rooke et al., 1989). The model of Hall and others predicts small or no northward motion between 40 and $25 \mathrm{Ma}$ around the Daito Ridge, with the majority of the northward drift occurring before and after this period of time (Hall et al., 1995c). However, our observation suggests rather rapid northward motion between 40 and $25 \mathrm{Ma}$ (Fig. 3). The model of Hall and others is based mainly on the paleomagnetic data from eastern Indonesia, which is a tectonically active region, and it strongly depends on the results from a single locality mean at about $40 \mathrm{Ma}$ (Hall et al., 1995a, b). Hence, we consider that this model may not be well constrained.

In Palau and Saipan, the easterly deflected declinations were observed in the lower to middle Miocene as well as in the Eocene and Oligocene (Haston and Fuller, 1991). This observation contradicts our model. On the other hand, the declinations of Palau and Saipan require significant rotation of the PHS Plate since the middle Miocene, which is inconsistent with the geology of the Japanese Islands, as mentioned above. The data from Palau and Saipan may have been affected by local tectonic movement because these islands belong to tectonically active regions, but further studies are needed to resolve the inconsistency.

Our model is consistent with the paleomagnetic data from eastern Indonesia in predicting the southward motion of eastern Indonesia between the Eocene and Oligocene. Although the amount of the southward motion depends on the unknown opening direction of the West Philippine Basin, eastward or westward (in the geometry at $50 \mathrm{Ma}$ ), it can explain the paleolatitude data of Hall et al. (1995a, b) at least qualitatively. Queano et al. (2007) reported paleomagnetic data from the North Luzon, northern Philippines which indicate an $\sim 7^{\circ}$ northward movement of this region since $\sim 15 \mathrm{Ma}$. At the present time, this region is separated from the PHS Plate by the East Luzon Trough-Philippine Trench subduction zone, but it may have been a part of the PHS Plate before 3-5 Ma (Queano et al., 2007). The latitude of the Euler pole position of the PHS Plate since $15 \mathrm{Ma}$ is required to be similar to that of the collision zone between the IBM Arc and Southwest Japan based on the lack of significant movement of the collision zone, but it is difficult to constrain its longitude. If it is to the east of the collision zone and not very far from the PHS Plate, a northward motion of the PHS Plate larger than that at the Nankai Trough ( $\sim 3.5^{\circ}$ for the last $15 \mathrm{Ma}$ ) is predicted at the North Luzon due to the larger distance from the Euler pole, which is consistent with the observation.

Acknowledgments. The samples used in this study were collected under the project "Deep Sea Survey Technology for Natural Resources in Japan" conducted by the Japan Oil, Gas and Metals National Corporation. We thank Emi Kariya and Etsuko Usuda for their help with the measurements and the members of the Paleogeodynamics research group of the Geological Survey of Japan, AIST, for helpful discussions. Comments from Jason R. Ali and two anonymous reviewers improved the manuscript.

\section{References}

Amano, K., Multiple collision tectonics of the South Fossa Magna in Central Japan, Modern Geol., 15, 315-329, 1991.

Arason, P. and S. Levi, The maximum Likelihood solution for inclinationonly data, Eos Trans. AGU, 87(52), Fall Meet. Suppl., Abstract GP21B1312, 2006.

Chamot-Rooke, N., K. Tamaki, and K. Kobayashi, Deskewed magnetic profiles of the Shikoku Basin and the past kinematics of the Philippine Sea Plate, Eos Trans., 70, 1365-1366, 1989.

Deschamps, A. and S. Lallemand, The West Philippine Basin: An Eocene to early Oligocene back arc basin opened between two opposed subduction zones, J. Geophys. Res., 107, doi:10.1029/2001JB001706, 2002.

Duncan, R. A. and D. A. Clague, Pacific plate motion recorded by linear volcanic chains, in The Pacific Ocean, edited by A. E. M. Nairn, F. G. Stehli, and S. Uyeda, 89-121, The Ocean basin and margins, vol. 7A, Plenum Press, 1985.

Gladstein, F., J. Ogg, and A. Smith, A Geologic Time Scale 2004, 589 pp., Cambridge University Press, Cambridge, 2004.

Hall, R., Cenozoic geological and plate tectonic evolution of SE Asia and the SW Pacific: computer-based reconstructions, model and animations, J. Asian Earth Sci., 20, 353-431, 2002.

Hall, R., J. R. Ali, C. D. Anderson, and S. J. Baker, Origin and motion history of the Philippine Sea Plate, Tectonophysics, 251, 229-250, 1995a.

Hall, R., J. R. Ali, and C. D. Anderson, Cenozoic motion of the Philippine Sea Plate: Paleomagnetic evidence from eastern Indonesia, Tectonics, 14, 1117-1132, $1995 \mathrm{~b}$.

Hall, R., M. Fuller, J. R. Ali, and C. D. Anderson, The Philippine Sea Plate: Magnetism and reconstructions, in Active Margins and Marginal Basins of the Western Pacific, edited by Taylor, B. and J. Natland, AGU Geophys. Monogr., 88, 371-404, 1995c.

Haston, R. B. and M. Fuller, Paleomagnetic data from the Philippine Sea plate and their tectonic significance, J. Geophys. Res., 96, 6073-6098, 1991.

Haston, R., M. Fuller, and E. Schmidtke, Paleomagnetic results from Palau, West Caroline Islands: A constraint on Philippine Sea plate motion, Geology, 16, 654-657, 1988.

Hickey-Vargas, R., Basalt and tonalite from the Amami Plateau, northern West Philippine Basin: New Early Cretaceous ages and geochemical results, and their petrologic and tectonic implications, Island Arc, 14, 653-665, 2005.

Hilde, T. W. C. and C.-S. Lee, Origin and evolution of the West Philippine Basin: A new interpretation, Tectonophysics, 102, 85-104, 1984.

Huang, J. and D. Zhao, High-resolution mantle tomography of China and surrounding regions, J. Geophys. Res., 111, B09305, doi:10.1029/2005JB004066, 2006.

Ishizuka, O., J.-I. Kimura, Y. B. Li, R. J. Stern, M. K. Reagan, R. N. Taylor, Y. Ohara, S. H. Bloomer, T. Ishii, U. S. Hargrove III, and S. Haraguchi, Early stages in the evolution of Izu-Bonin arc volcanism: New age, chemical, and isotopic constraints, Earth Planet. Sci. Lett., 250, 385-401, 2006.

Iwamoto, H., M. Yamamoto, N. Seama, K. Kitada, T. Matsuno, Y. Nogi, T. Goto, T. Fujiwara, K. Suyehiro, and T. Yamazaki, Tectonic Evolution of the Central Mariana Trough, Eos Trans., 83, 2002 Fall Meeting Suppl., 2002. 
Jolivet, L., P. Huchon, and C. Rangin, Tectonic setting of Western Pacific marginal basins, Tectonophysics, 160, 23-47, 1989.

Kato, T., Y. Kotake, S. Nakao, J. Beavan, K. Hirahara, M. Okada, M. Hoshiba, O. Kamigaichi, R. B. Feir, P. H. Park, M. D. Gerasimenko, and M. Kasahara, Initial results from WING, the continuous GPS network in the western Pacific area, Geophys. Res. Lett., 25, 369-372, 1998.

Kimura, J.-I., R. J. Stern, and T. Yoshida, Reinitiation of subduction and magmatic responses in SW Japan during Neogene time, Geol. Soc. Am. Bull., 117, 969-986, 2005.

Kinoshita, H., Paleomagnetism of sediment cores from Deep Sea Drilling Project Leg 58, Philippine Sea, Init. Rep. DSDP, 58, 765-768, 1980.

Kirschvink, J. L., The least-squares line and plane and the analysis of paleomagnetic data, Geophys. J. R. Astron. Soc., 62, 699-718, 1980.

Kodama, K., B. H. Keating, and C. E. Helsley, Paleomagnetism of the Bonin Islands and its tectonic significance, Tectonophysics, 95, 25-42, 1983.

Koyama, M., S. M. Cisowski, and P. Pezard, Paleomagnetic evidence for northward drift and clockwise rotation of the Izu-Bonin forearc since the early Oligocene, Proc. ODP Sci. Results, 126, 353-370, 1992.

Louden, K. E., Paleomagnetism of DSDP sediments, phase shifting of magnetic anomalies, and rotations of the West Philippine Basin, J. Geophys. Res., 82, 2989-3002, 1977.

Matsuda, N., H. Tsuchiya, K. Matsumoto, N. Saito, and M. Endo, Development and operation of deep-sea boring machine system by operating group on the deep-sea boring machine system, Shigen-to-Sozai, 120, 425-430, 2004 (in Japanese with English abstract).

Matsumoto, K. and S. Sarata, Development of Deep-sea Boring Machine System, Shigen-to-Sozai, 112, 1015-1020, 1996 (in Japanese with English abstract).

Nakamura, K., K. Shimazaki, and N. Yonekura, Subduction, bending and eduction. Present and Quaternary tectonics of the northern border of the Philippine Sea plate, Bull. Soc. Géol. Fr., 26, 221-243, 1984.

Okino, K., Y. Shimakawa, and S. Nagaoka, Evolution of the Shikoku Basin, J. Geomag. Geoelectr., 46, 463-479, 1994.

Okino, K., Y. Ohara, S. Kasuga, and Y. Kato, The Philippine Sea: New survey results reveal the structure and the history of the marginal basins, Geophys. Res. Lett., 26, 2287-2290, 1999.

Queano, K. L., J. R. Ali, J. Milsom, J. C. Airchison, and M. Pubellier, North Luzon and the Philippine Sea Plate motion model: Insights following paleomagnetic, structural, and age-dating investigations, J. Geophys. Res., 112, B05101, doi:10.1029/2006JB004506, 2007.

Sdrolias, M., W. R. Roset, and R. D. Muller, An expression of Philippine Sea plate rotation: the Parece Vela and Shikoku Basins, Tectonophysics, 394, 69-86, 2004.

Seno, T. and S. Maruyama, Paleogeographic reconstruction and origin of the Philippine Sea, Tectonophysics, 102, 53-84, 1984.

Seno, T., S. Stein, and A. E. Gripp, A model for the motion of the Philippine Sea Plate consistent with NUVEL-1 and geological data, J. Geophys. Res., 98, 17941-17948, 1993.

Sharp, W. D. and D. A. Clague, 50-Ma initiation of Hawaii-Emperor bend records major change in Pacific Plate motion, Science, 313, 1281-1284, 2006.

Shih, T.-C., Marine magnetic anomalies from the West Philippine Sea: Implications for the evolution of marginal basins, in The Tectonic and Geologic Evolution of Southeast Asian Seas and Islands, edited by Hayes, D. E., AGU Geophys. Monogr., 23, 49-76, 1980.

Shipboard Scientific Party, Site 1201, Proc. ODP, Init. Reps., 195, 1-233, doi:10.2973/odp.proc.ir.195.104.2002, 2002.

Takahashi, M. and K. Saito, Miocene intra-arc bending at an arc-arc collision zone, central Japan: Reply, Island Arc, 8, 117-123, 1999.

Yamazaki, T. and Y. Okamura, Subducting seamounts and deformation of overriding forearc wedges around Japan, Tectonophysics, 160, 207-229, 1989.

Yamazaki, T. and R. J. Stern, Topography and magnetic vector anomalies in the Mariana Trough, JAMSTEC J. Deep Sea Res., 13, 31-45, 1997.

T. Yamazaki (e-mail: toshi-yamazaki@aist.go.jp), M. Takahashi, Y. Iryu, T. Sato, M. Oda, H. Takayanagi, S. Chiyonobu, A. Nishimura, T.

Nakazawa, and T. Ooka 